\title{
Extrasynaptic Targeting of NMDA Receptors Following D1 Dopamine Receptor Activation and Cocaine Self-Administration
}

\author{
Pavel I. Ortinski, ${ }^{1}{ }^{1}$ Jill R. Turner, ${ }^{2}$ and R. Christopher Pierce ${ }^{1}$ \\ ${ }^{1}$ Department of Psychiatry and ${ }^{2}$ Department of Pharmacology, Perelman School of Medicine at the University of Pennsylvania, Philadelphia, Pennsylvania \\ 19104
}

We previously showed that after repeated exposure to cocaine, D1-like dopamine receptor (D1DR) stimulation reverses plastic changes of AMPA receptor-mediated signaling in the nucleus accumbens shell. However, there is little information on the impact of cocaine self-administration on D1-NMDA receptor interactions in this brain region. Here, using whole-cell patch-clamp recordings, we assessed whether cocaine self-administration alters the effects of D1DR stimulation on synaptic and extrasynaptic NMDA receptors (NMDARs). In slices from cocaine-naive rats, pretreatment with a D1DR agonist decreased synaptic NMDAR-mediated currents and increased the contribution of extrasynaptic NMDARs. In contrast, neither cocaine self-administration alone nor cocaine experience followed by D1DR stimulation had an effect on synaptic or extrasynaptic NMDAR signaling. Activation of extrasynaptic NMDARs relies on the availability of extracellular glutamate, which is regulated primarily by glutamate transporters. In cocaine-experienced animals, relative to cocainenaive rats, administration of a glutamate reuptake blocker, DL-threo- $\beta$-benzyloxyaspartic acid, revealed increased extrasynaptic NMDAR activity and stronger baseline activity of glutamate uptake transporters. In cocaine-naive rats, the D1DR-mediated increase in extrasynaptic NMDAR signaling was independent of the activity of glutamate reuptake transporters. Together, these results indicate that cocaine experience blunts the influence of D1DRs on synaptic and extrasynaptic NMDAR signaling. Additionally, prior cocaine selfadministration limits activation of the extrasynaptic NMDAR pool by increasing glutamate reuptake. These findings outline a pattern of adaptive interactions between D1DRs and NMDARs in the nucleus accumbens shell and demonstrate upregulation of extrasynaptic NMDAR signaling as a novel consequence of cocaine self-administration.

\section{Introduction}

Repeated exposure to cocaine results in changes in accumbens glutamate transmission that contribute to the maintenance of cocaine self-administration as well as the reinstatement of cocaine seeking (Cornish and Kalivas, 2000; Park et al., 2002; Schmidt and Pierce, 2010; Suto et al., 2010). Although much of the work in this area focuses on changes in AMPA receptormediated neurotransmission, NMDARs are critically involved in neuroplasticity associated with drug addiction (for review, see Lau and Zukin, 2007). Evidence from behavioral studies suggests that NMDARs play a role in the development of locomotor sensitization to cocaine (Pulvirenti et al., 1991) and acquisition of

Received Dec. 14, 2012; revised March 22, 2013; accepted April 24, 2013.

Author contributions: P.I.O. designed research; P.I.O. and J.R.T. performed research; P.I.O. and J.R.T. analyzed data; P.I.O. and R.C.P. wrote the paper.

This work was funded by National Institutes of Health Grants K01DA031747 to P.I.0., R01 DA22339 to R.C.P., and K02 DA18678 to R.C.P.J.R.T. was supported by K99 DA032681 and P50-CA143187. We thank Drs. Stefano Vicini and Douglas A. Coulter for valuable comments on the manuscript and Dr. Michael B. Robinson for advice on biochemical analyses.

The authors declare no competing financial interests.

Correspondence should be addressed to Pavel I. Ortinski, Department of Psychiatry, Center for Neurobiology and Behavior, Perelman School of Medicine at the University of Pennsylvania, TRL Suite 1110, 125 S. 31st Street, Philadelphia, PA 19104. E-mail: ortinski@mail.med.upenn.edu,

DOI:10.1523/JNEUROSCI.5730-12.2013

Copyright $\odot 2013$ the authors $\quad 0270-6474 / 13 / 339451-11 \$ 15.00 / 0$ cocaine self-administration (Pulvirenti et al., 1992; Schenk et al., 1993), as well as extinction and reinstatement of cocaine seeking (De Vries et al., 1998; Cornish et al., 1999; Famous et al., 2007; Thanos et al., 2011).

Interactions between glutamate and dopamine systems play a central role in cocaine-mediated plasticity in the nucleus accumbens. We recently demonstrated that stimulation of accumbens shell D1-like dopamine receptors (D1DRs) normalizes synaptic activity of AMPA receptors following abstinence from cocaine self-administration (Ortinski et al., 2012). Dopamine receptor activation following cocaine exposure also influences NMDAR expression and function (for review, see Wang et al., 2012). In fact, a number of behavioral and molecular responses triggered by exposure to cocaine and other psychostimulants rely on D1DR-NMDAR interactions (Hanson et al., 1995; Parada and Soares-da-Silva, 2000; Dudman et al., 2003; Heusner and Palmiter, 2005; Sun et al., 2009; Ren et al., 2010; Beutler et al., 2011; Lee et al., 2011). Additionally, there is support for the idea that cocaine treatment has unique effects on subpopulations of NMDARs. Thus, a single injection of cocaine facilitates the development of silent synapses containing NMDA, but not AMPA, receptors (Huang et al., 2009). Cocaine-induced silent synapse formation correlates with an increased function of synaptic NR2B-subunit-containing NMDARs in the nucleus accumbens (Brown et al., 2011). An increase in synaptic NR2B signaling 
following acute cocaine treatment also has been reported in the ventral tegmental area, where it has been linked to activation of D1DRs (Schilström et al., 2006).

Synaptic and extrasynaptic NMDARs have been shown to play unique roles in psychiatric illnesses associated with impaired striatal function (for review, see Lau and Zukin, 2007; Gladding and Raymond, 2011; Petralia, 2012). Activation of synaptic and extrasynaptic NMDARs has been linked to differential effects on cell survival (Hardingham et al., 2002; Léveillé et al., 2008), nuclear structure (Wittmann et al., 2009), neuronal development (Komuro and Rakic, 1993), neuronal excitability (Chalifoux and Carter, 2011), and synaptic plasticity (Kervern et al., 2012). The extent to which D1DR activation affects the balance between these NMDAR populations in the nucleus accumbens of cocainenaive and cocaine-experienced rats is unknown. In the present study, we demonstrate that both cocaine experience and D1DR stimulation facilitate targeting of NMDARs to extrasynaptic sites. However, following cocaine exposure, but not following D1DR stimulation, activation of these NMDARs is limited by increased reuptake of synaptic glutamate.

\section{Materials and Methods}

Animals. Male Sprague Dawley rats (Rattus norvegicus) weighing 300$350 \mathrm{~g}$ were obtained from Taconic Laboratories. Animals were individually housed, with food and water available ad libitum in the home cage. A $12 \mathrm{~h}$ light/dark cycle was used with the lights on at 7 A.M. All behavioral training was performed during the light cycle. All experimental protocols were approved by the Institutional Animal Care and Use Committee of the University of Pennsylvania.

Surgery and self-administration training. Before surgery, the rats were anesthetized with injections of $80 \mathrm{mg} / \mathrm{kg}$ ketamine (i.p.) and $12 \mathrm{mg} / \mathrm{kg}$ xylazine (i.p.). An indwelling catheter (CamCaths) was placed into the right jugular vein and sutured in place. The catheter was routed subcutaneously to a mesh platform placed and sutured between the shoulder blades. Catheters were flushed daily with $0.3 \mathrm{ml}$ of the antibiotic Timentin $(0.93 \mathrm{mg} / \mathrm{ml})$ dissolved in heparinized saline. The catheters were sealed with plastic obturators when not in use. After a $7 \mathrm{~d}$ recovery period from surgery, the rats were placed in operant chambers (Med Associates) and allowed to lever-press for intravenous cocaine infusions $(0.25 \mathrm{mg}$ of cocaine per $56 \mathrm{ml}$ of saline over a $5 \mathrm{~s}$ infusion) during daily $2 \mathrm{~h}$ selfadministration sessions. Each cocaine infusion was followed by a $20 \mathrm{~s}$ time-out period, during which responses had no scheduled consequences. The rats were initially trained using a fixed ratio (FR) 1 schedule of reinforcement. When stable responding was achieved under the FR1 schedule, they were switched to an FR5 schedule. Rats self-administered cocaine for $14 \mathrm{~d}$ and were paired with yoked saline controls. The yoked animals received an infusion of saline every time its pair received cocaine. There were no consequences to lever pressing by the yoked saline animals.

Nucleus accumbens slices. The rats were decapitated following isoflurane anesthesia $24 \mathrm{~h}$ after the last cocaine self-administration session. The brain was removed and coronal slices $(300 \mu \mathrm{m})$ containing the nucleus accumbens were cut with a Vibratome (VT1000S, Leica Microsystems) in an ice-cold artificial CSF (ACSF) solution, in which $\mathrm{NaCl}$ was replaced by an equiosmolar concentration of sucrose. ACSF consisted of (in mM) the following: $130 \mathrm{NaCl}, 3 \mathrm{KCl}, 1.25 \mathrm{NaH}_{2} \mathrm{PO}_{4}, 26 \mathrm{NaHCO}_{3}, 10$ glucose, 1 $\mathrm{MgCl}_{2}$, and $2 \mathrm{CaCl}_{2}, \mathrm{pH} 7.2-7.4$ when saturated with $95 \% \mathrm{O}_{2} / 5 \% \mathrm{CO}_{2}$. Slices were incubated in ACSF at $32-34^{\circ} \mathrm{C}$ for $45 \mathrm{~min}$ and kept at $22-25^{\circ} \mathrm{C}$ thereafter, until transfer to the recording chamber. A subset of slices from each animal was incubated with ACSF supplemented with SKF38393 (10 $\mu \mathrm{M}$; Sigma-Aldrich) for 1-3 h. The prolonged treatment was chosen to approximate a cocaine self-administration session in which activation of D1DR is sustained for a period of time and results in persistent neuroadaptations. The partial agonist SKF38393 was chosen based on similarity of its pharmacological profile to dopamine (Ryman-Rasmussen et al., 2005) and its ability to modulate excitability of the nucleus accumbens neurons with efficiency that matches or exceeds that of the full agonist SKF81297 (Johansen et al., 1991). Slices pre-exposed to SKF38393 were washed with regular ACSF for at least $10 \mathrm{~min}$ before initiation of the recordings. The osmolarity of all solutions was 305-315 mOsm. Slices were viewed using infrared differential interference contrast optics under an upright microscope (Eclipse FN1, Nikon Instruments) with a $40 \times$ water-immersion objective.

Electrophysiology. The recording chamber was continuously perfused (1-2 $\mathrm{ml} / \mathrm{min})$ with oxygenated ACSF heated to $32 \pm 1{ }^{\circ} \mathrm{C}$ using an automatic temperature controller (Warner Instruments). NMDARmediated responses were pharmacologically isolated in low $\mathrm{Mg}^{2+}(0.005$ $\mathrm{mM})$ ACSF supplemented with the glycine site coagonist D-serine $(10 \mu \mathrm{M})$ and the AMPA receptor antagonist DNQX $(10 \mu \mathrm{M})$. In experiments involving glutamate reuptake blocker DL-threo- $\beta$-benzyloxyaspartic acid (TBOA), DNQX was omitted and NMDAR-mediated evoked EPSCs (eEPSCs) and spontaneous EPSCs (sEPSCs) were isolated by subtracting the average EPSC in the presence of NMDAR antagonist DL-AP5 $(50 \mu \mathrm{M})$ from the average EPSC before DL-AP5 application. In all experiments, the eEPSC averages were computed from 5-10 responses and the sEPSC averages were computed from 50-100 responses. Picrotoxin $(100 \mu \mathrm{M})$ was added to all solutions to block the $\mathrm{GABA}_{\mathrm{A}}$ receptor-mediated currents. Recording pipettes were pulled from borosilicate glass capillaries (World Precision Instruments) to a resistance of 4-7 M $\Omega$ when filled with the intracellular solution. The intracellular solution contained the following (in mM): 145 potassium gluconate, $2 \mathrm{MgCl}_{2}, 2.5 \mathrm{KCl}, 2.5 \mathrm{NaCl}$, 0.1 BAPTA, 10 HEPES, 2 Mg-ATP, 0.5 GTP-Tris, and 1 QX-314, pH 7.2-7.3 with $\mathrm{KOH}$, osmolarity $280-290 \mathrm{mOsm}$. Medium spiny neurons (MSNs) in the nucleus accumbens shell were identified by their morphology and the low resting membrane potential $(-70$ to $-85 \mathrm{mV})$. All recordings were conducted in whole-cell voltage-clamp mode $\left(V_{\mathrm{h}}=\right.$ $-70 \mathrm{mV}$ ). Drugs were applied via the Y-tube perfusion system (Murase et al., 1989) modified for optimal solution exchange in brain slices (Hevers and Lüddens, 2002). All recordings were conducted with a MultiClamp700B amplifier (Molecular Devices). Currents were low-pass filtered at $2 \mathrm{kHz}$ and digitized at $20 \mathrm{kHz}$ using a Digidata 1440A acquisition board and pClamp10 software (both from Molecular Devices). Access resistance $(10-30 \mathrm{M} \Omega$ ) was monitored throughout the recordings by injection of $10 \mathrm{mV}$ hyperpolarizing pulses and data were discarded if access resistance changed by $>25 \%$ over the course of data acquisition. Evoked responses were triggered by $100 \mu$ s constant-current pulses generated by an A310 Accupulser (World Precision Instruments) and delivered at $0.1 \mathrm{~Hz}$ via a bipolar tungsten stimulation electrode positioned within $100 \mu \mathrm{m}$ of the recorded cell. The amplitude of the current pulses was controlled by a stimulus isolator (ISO-Flex, AMPI).

Western blots. Nucleus accumbens slices were prepared as above and half of the slices from each brain were pretreated with SKF38393 $(10 \mu \mathrm{M})$ for $1.5 \mathrm{~h}$. The shell of the nucleus accumbens was isolated by tissue punches and Western blotting was performed as described previously (Portugal et al., 2012). Briefly, proteins from treated tissues were resolved in 10\% SDS-PAGE and transferred to nitrocellulose membranes. Membranes were incubated with LI-COR blocking buffer (LI-COR) for $1 \mathrm{~h}$ at room temperature, then the blots were reacted overnight at $4^{\circ} \mathrm{C}$ with primary antibodies (GluN1 (1:500; Millipore Bioscience Research Reagents), GluN 2A (1:1000; Cell Signaling Technology), GluN 2B (1:1000; Cell Signaling Technology), EAAT3 (1:200; Santa Cruz Biotechnology), GLAST (1:500; Miltenyi Biotech), or GLT-1 (1:1000, Abcam), and $\beta$-tubulin (1:2000; BD Biosciences). After washing in PBS with $0.1 \%$ Triton X-100 (PBS-T), the blots were incubated in fluorescent secondary antibodies (1:20,000, LI-COR) in LI-COR blocking buffer for $1 \mathrm{~h}$ at room temperature. Membranes were then washed and immunolabeling detection and densitometry measurements were performed using the LI-COR Odyssey System (LI-COR). Ratios of GluN1, GluN 2A, GluN 2B, EAAT3, GLAST, or GLT-1 to $\beta$-tubulin densities were calculated for each sample and analyzed across conditions.

Data analysis and statistics. All analyses of intracellular recordings were performed with Clampfit 10 (Molecular Devices). In TBOA experiments, NMDA eEPSCs were measured as eEPSC charge transfer normalized to the peak current amplitude. In MK-801 experiments, synaptic currents were evoked by paired pulses with the interstimulus interval of $100 \mathrm{~ms}$, delivered at $0.1 \mathrm{~Hz}$. To analyze the rate of MK-801 block, current charge 
A

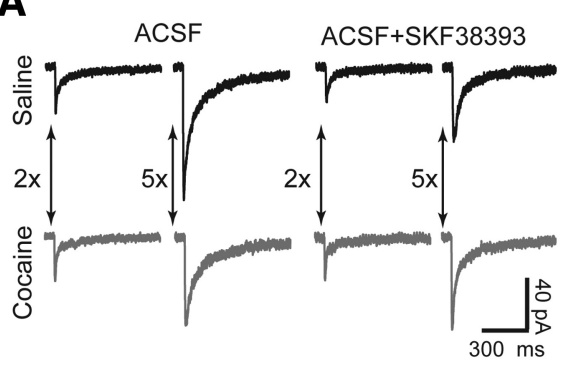

B

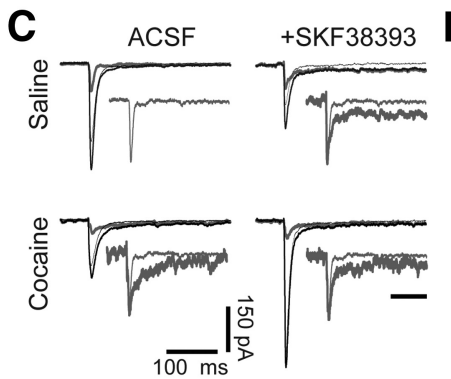

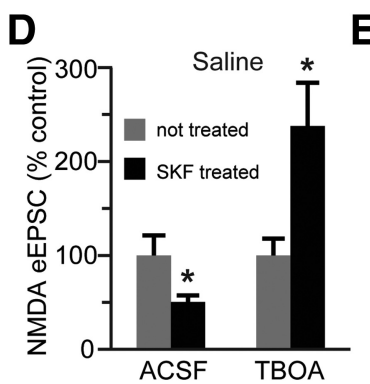

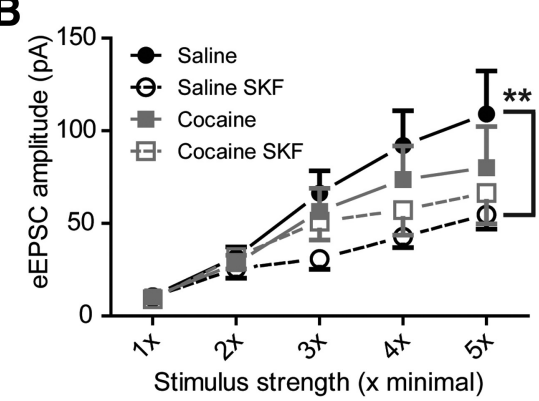

E

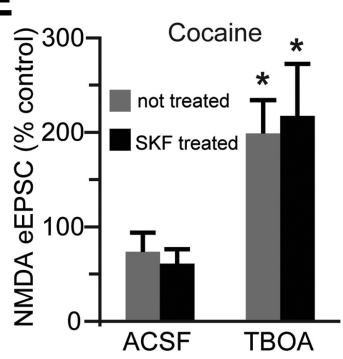

\section{Results}

D1DR stimulation, but not cocaine exposure, decreases synaptic NMDAR current

We began by pharmacologically isolating synaptic NMDAR responses in MSNs from the nucleus accumbens shell from yoked saline (cocaine-naive) and cocaine-experienced animals. Pretreatment of slices from yoked saline animals with the D1DR agonist SKF38393 (10 $\mu \mathrm{M})$ for $1-3 \mathrm{~h}$ resulted in a pronounced suppression of eEPSCs mediated by NMDARs, particularly at higher intensities of stimulation (Fig. $1 A, B$ ). Cocaine experience abolished this effect of SKF38393 across the entire range of stimulation intensities and, in the absence of D1DR stimulation, resulted in only a mild suppression of NMDARmediated eEPSCs (Fig. 1A,B).

Figure 1. Blockade of glutamate reuptake reverses the D1DR stimulation-induced decrease of NMDAR-mediated eEPSCS. $A$, Representative NMDAR eEPSC averages at low $(2 \times)$ and high $(5 \times)$ stimulation intensities following D1DR agonist (SKF38393, $10 \mu \mathrm{M}$ ) pretreatment of slices from yoked saline and cocaine-experienced animals. $\boldsymbol{B}$, An input-output relationship of NMDAR eEPSCs illustrates reduced synaptic strength following D1DR stimulation in slices from yoked saline rats $\left(F_{(3,20)}=6.206\right.$, Tukey's post hoc; $\left.{ }^{* *} p<0.01\right)$. C, Representative NMDAR eEPSC averages for TBOA experiments. Three traces are pictured in each experimental group: the combined NMDAR plus AMPAR eEPSC (thick black line), the AMPAR eEPSC isolated by application of DL-AP5 to the same cell (thin black line), and the subtracted NMDAR eEPSC (thick gray line). The inset for the saline ACSF group shows an expanded NMDAR eEPSC trace. In insets for all other groups, this trace is overlayed with the corresponding NMDAR eEPSCS. Amplitudes of overlayed traces are normalized for ease of comparison. Inset scale bar, $100 \mathrm{~ms}$. D, A D1DR agonist-induced decrease of NMDAR eEPSCs under normal recording conditions contrasts with D1DR agonist-induced increase of NMDAR eEPSCs under conditions of glutamate reuptake transporter blockade by TBOA (30 $\mu \mathrm{m} ; t_{(9)}=2.38$ for SKF-treated ACSF; $t_{(15)}=2.64$ for SKF-treated TBOA; $n=5-9$ cells; ${ }^{*} p<0.05$ vs respective not-treated group). $\boldsymbol{E}$, (ocaine treatment slightly decreases the NMDAR eEPSCs recorded in normal ACSF, but significantly increases the NMDAR eEPSCs recorded in the presence of TBOA. D1DR stimulation has no effect on NMDAR-mediated currents in either recording condition. The data are expressed as percentage difference from the respective not-treated saline group $\left(t_{(17)}=2.22\right.$ for not-treated TBOA; $t_{(11)}=2.41$ for SKF-treated TBOA; ${ }^{*} p<0.05 ; n=5-11$ cells).

transfer during individual responses to the second of the paired pulses was calculated. These values were normalized to an average charge transfer of three responses in the absence of MK-801 in each cell and fitted with the monoexponential function. To analyze the fraction of extrasynaptic NMDARs, we evaluated whole-cell responses to NMDA $(100 \mu \mathrm{M})$ before the synaptic current stimulation in the presence of use-dependent NMDAR antagonist MK-801 $(40 \mu \mathrm{M})$ and whole-cell responses to NMDA $(100 \mu \mathrm{M})$ following blockade of synaptic currents and a wash of MK-801 for at least $2 \mathrm{~min}$. The fraction of extrasynaptic NMDARs was computed for each cell as a ratio of whole-cell NMDA response after MK-801 stimulation to whole-cell NMDA response before MK-801 stimulation. Tonic NMDAR-mediated currents were computed as the difference in mean baseline current during the $3 \mathrm{~s}$ recording segments devoid of synaptic events before and after application of DL-AP5 (50 $\mu \mathrm{M})$. Alternatively, tonic NMDA currents were evaluated based on Gaussian fits of $3 \mathrm{~s}$ segments of current baseline before and after application of DL-AP5. These two methods yielded equivalent results and summary histograms were constructed based on mean baseline current measurements. Current density was calculated as peak amplitude divided by the cell capacitance. Cell capacitance was calculated from the current response to a hyperpolarizing $10 \mathrm{mV}$ pulse with the following equation: $C_{\mathrm{m}}=$ $\tau^{*}\left(R_{\mathrm{s}}+R_{\mathrm{m}}\right) / R_{\mathrm{s}}{ }^{*} R_{\mathrm{m}}$, where $\tau$ is the time constant of the exponentially decaying capacitive current, $R_{\mathrm{m}}$ is membrane resistance, and $R_{\mathrm{s}}$ is series resistance. Cells from 3-7 animals were analyzed in each experimental condition. The data were expressed as mean \pm SEM. Statistical comparisons were done using two-tailed unpaired Student's $t$ tests or ANOVA as indicated. Statistical analyses were performed with Microsoft Excel or GraphPad Prism 5.0.4 for Windows.

\section{D1DR stimulation, but not cocaine exposure, increases extrasynaptic NMDAR currents}

To begin to evaluate the role of extrasynaptic NMDARs, we recorded NMDARmediated eEPSCs in the presence of TBOA $(30 \mu \mathrm{M})$, the nontransportable antagonist of glutamate reuptake transporters. Blockade of glutamate reuptake facilitates recruitment of extrasynaptic NMDARs by allowing synaptically released glutamate to "spillover" to extra2007; Scimemi et al., 2009). Because glutamate spillover could be expected to affect both the amplitude and duration of eEPSCs, we evaluated the total NMDAR-mediated charge transfer normalized to the current peak during electrically stimulated synaptic release (Lozovaya et al., 2004). In the presence of TBOA, SKF38393 pretreated slices from saline controls showed a 2.4fold increase in the NMDAR-mediated normalized charge transfer (Fig. 1C,D). A comparable increase was observed also in slices from cocaine self-administering animals with no additional effect of SKF38393 pretreatment (relative to saline ACSF: $198.7 \pm 35.4 \%$ without SKF38393 and $217.1 \pm 55.3 \%$ with SKF38393; Fig. 1C,E). Interestingly, in cocaine-experienced animals, TBOA eliminated the mild suppression of eEPSC amplitudes in input-output curves at higher stimulation intensities, although the eEPSC amplitudes of SKF38393-treated slices from saline animals remained depressed (eEPSC amplitudes at $1 \times$ : saline, $9.9 \pm 1.1 \mathrm{pA}$; saline SKF, $9.2 \pm 1.9 \mathrm{pA}$; cocaine, $10.1 \pm 1.1 \mathrm{pA}$; cocaine SKF, $8.8 \pm 1.1 \mathrm{pA}$; eEPSC amplitudes at $5 \times$ : saline, $335.8 \pm 82.2 \mathrm{pA}$; saline SKF, $195 \pm$ 31 pA; cocaine, $348.8 \pm 68.7$ pA; cocaine SKF, $450.4 \pm 116.7$ $\mathrm{pA} ; n=7-10$ cells). These results indicate that cocaine experience or D1DR stimulation increases NMDAR-mediated signaling under conditions that favor activation of extrasynaptic NMDARs. This could be due to an increase in extrasynaptic NMDAR signaling and/or an increase in efficiency of glutamate reuptake transporters themselves. synaptic sites (Tzingounis and Wadiche, 
To explore the possible increase of extrasynaptic NMDAR signaling, we recorded whole-cell responses to NMDA $(100 \mu \mathrm{M})$ before and after stimulation of synaptic NMDARs in the presence of dizocilpine (MK-801, $40 \mu \mathrm{M})$. MK-801 is an open channel blocker that depresses synaptic eEPSCs in a use-dependent manner (Huettner and Bean, 1988). Wholecell application of NMDA allowed us to estimate the fraction of total NMDA channels that remained available following the block of synaptic responses by MK-801, reflecting the size of the extrasynaptic pool of NMDARs. Between the cocaine-naive and cocaine-experienced groups, there was no difference in the relative amplitude of currents mediated by extrasynaptic NMDARs. MK-801 blocked $95.3 \pm 0.6 \%$ of total NMDAR current in the saline group and $95.1 \pm 0.6 \%$ of total NMDAR current in the cocaine group. There was also no effect of SKF38393 treatment on extrasynaptic NMDAR current in the cocaine group (MK-801 blocked $94.5 \pm 1 \%$ of total NMDAR current). However, and in sharp contrast to synaptic eEPSCs, D1DR stimulation in the cocaine-naive group led to a $110 \%$ increase in the relative amplitude of currents mediated by extrasynaptic NMDARs (Fig. $2 A, B$ ). In this group, MK801 blocked $90.1 \pm 1.8 \%$ of the total NMDAR-mediated current. It is important to note that the extrasynaptic NMDA receptors available after the MK-801 block likely represent a pool of receptors located distant to synaptic release sites (Scimemi et al., 2004). It is also significant that in the absence of synaptic stimulation, MK-801 did not affect the amplitude of eEPSCs (100.7 $\pm 10.4 \%$ of baseline responses, $n=4$ ) indicating that tonically active NMDARs did not measurably contribute to the eEPSC peak.

We next examined the rate of block of eEPSC by MK-801and found no group differences with the exception of the slightly faster block in the saline ACSF group (Fig. $2 C-F$ ). The rate of MK-801 block reflects the NMDAR open probability convolved with the probability of glutamate release. Therefore, the lack of differences in this rate indicates that the combined contribution of these parameters remains unchanged across our treatment conditions. Together, the eEPSC and MK-801 experiments indicate that there is a reduced contribution of synaptic NMDARs, but increased contribution of extrasynaptic NMDARs, in slices from yoked saline animals exposed to D1DR stimulation. Previous history of cocaine administration eliminates the effects of D1DR stimulation at both the synaptic and the
A

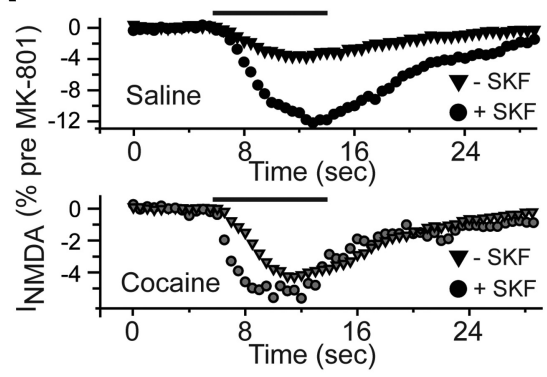

C
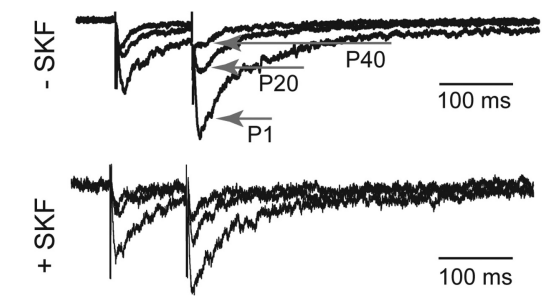

E

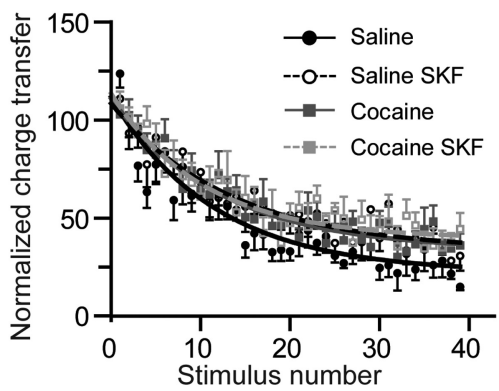

B

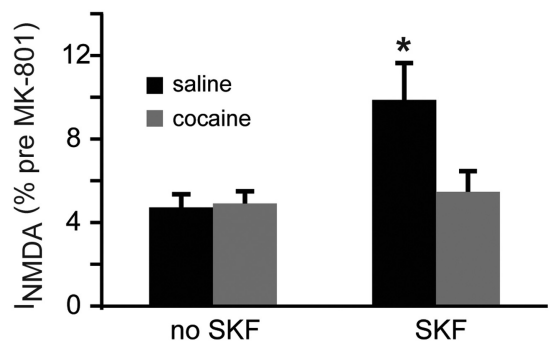

D

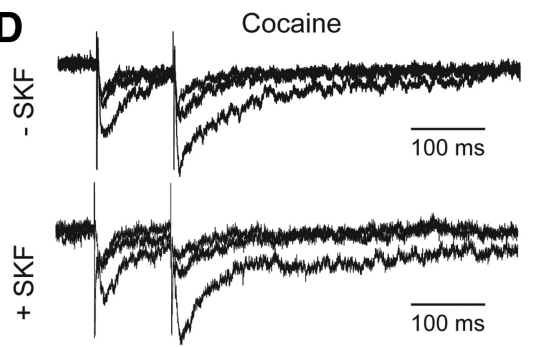

$\mathbf{F}$

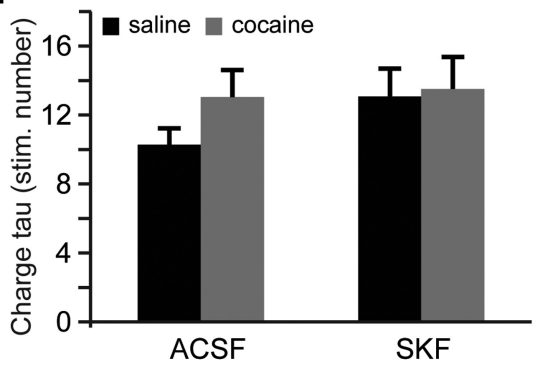

Figure 2. Extrasynaptic NMDAR-mediated currents increase following D1DR stimulation. $\boldsymbol{A}$, Time course of whole-cell NMDA (100 $\mu$, solid black line) responses after blockade of synaptic NMDARs by MK-801 (40 $\mu \mathrm{m})$ is expressed as a fraction of whole-cell NMDA responses measured before MK-801 application. $\boldsymbol{B}$, Bar histograms illustrating an increase in extrasynaptic NMDAR-mediated currents in slices from cocaine-naive rats following D1DRstimulation ( $t_{(11)}=2.54 ;{ }^{*} p<0.05$ vs saline no SKF; $n=6-11$ cells). $C, D$, Current responses to the first (P1), $20^{\text {th }}$ (P20) and $40^{\text {th }}$ (P40) stimulation pulses illustrate use-dependent block of NMDA eEPSCs by MK-801 across the experimental groups. Current amplitudes are normalized to the first eEPSC in the saline no-SKF group for ease of comparison. $\boldsymbol{E}$, A summary of the time course of synaptic responses in the presence of MK-801 illustrates a slight increase in the rate of MK- 801 block in the saline group. $\boldsymbol{F}$, Bar histograms summarizing the rate of block (expressed as stimulation pulse number) by MK-801.

A
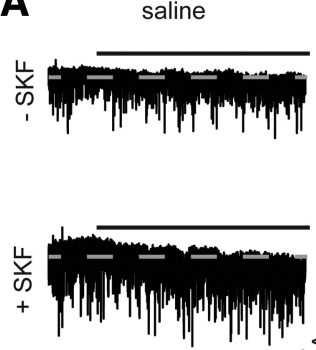

$\frac{1}{20 \mathrm{~s}}$ 离
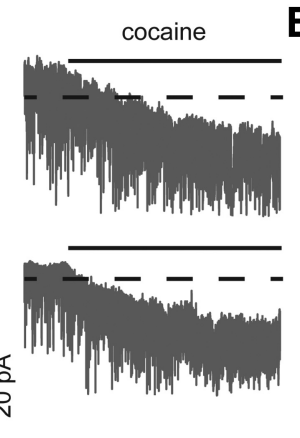

B

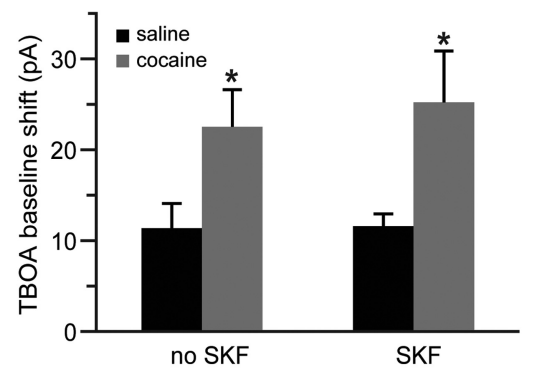

Figure 3. Glutamate reuptake is elevated following cocaine self-administration. $\boldsymbol{A}$, Current traces, illustrating a shift of baseline holding current during TBOA ( $30 \mu \mathrm{m}$ ) application (solid black lines). Dotted lines are centered at the mean holding current before application of TBOA. TBOA often induced large synchronous SEPSCS, which were clipped in this panel for display purposes. $\boldsymbol{B}, A$ summary of TBOA-induced mean current amplitudes. A significant increase is observed in slices from the cocaine-experienced group. D1DR stimulation has no effect on this increase $\left(t_{(12)}=2.28\right.$ for cocaine no SKF; $t_{(13)}=2.82$ for cocaine SKF; ${ }^{*} p<0.05$ vs respective saline group; $n=7-13$ cells).

extrasynaptic NMDAR pools. Moreover, the lack of effect of cocaine self-administration in MK-801 experiments combined with potentiation of NMDA eEPSCs in the presence of TBOA suggest that differences in NMDAR signaling following cocaine self- 
A
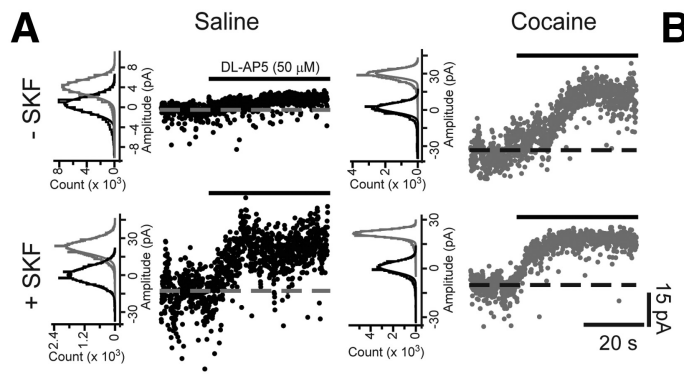

B

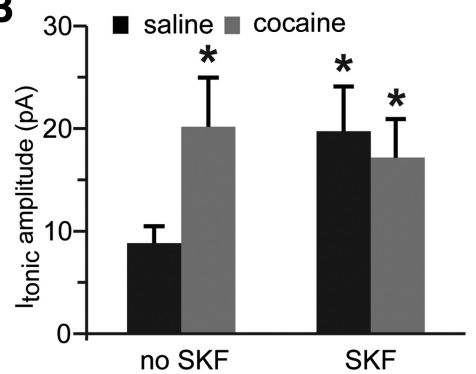

Figure 4. Blockade of glutamate reuptake reveals increased tonic NMDAR-mediated currents following cocaine selfadministration and D1DR stimulation. $\boldsymbol{A}$, NMDAR-mediated tonic currents were measured as a shift of baseline holding current following application of DL-AP5 (solid black lines) in the absence (top row) and presence (bottom row) of SKF38393 pretreatment. Dotted lines are centered at the mean holding current before application of DL-AP5. To the left of the traces are Gaussian-fitted distributions of the amplitude of baseline noise before (black) and after (gray) DL-AP5 application. The displayed fits are to the portions of the distributions not skewed by synaptic events. Notice the differences in the onset of DL-AP5 block likely due to variation in cell accessibility between slices. $\boldsymbol{B}$, Bar histograms summarizing tonic NMDAR-mediated current amplitudes across the experimental groups $\left(t_{(16)}=2.35\right.$ for saline SKF; $t_{(17)}=2.15$ for cocaine no SKF; $t_{(15)}=2.21$ for cocaine SKF; ${ }^{*} p<0.05$ vs saline no SKF; $n=8-11$ cells).

A
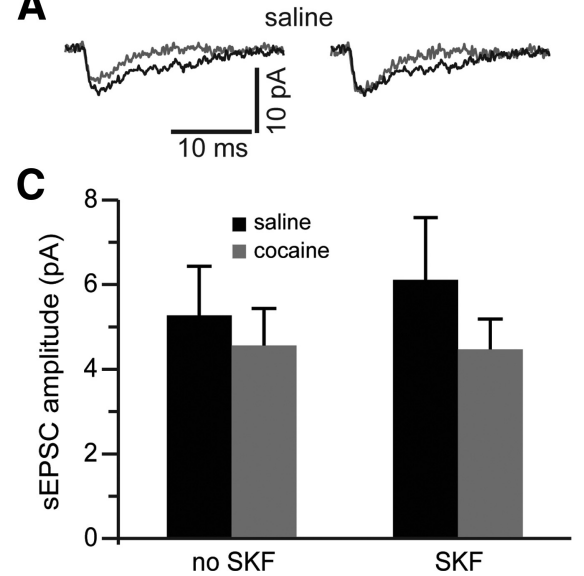

B

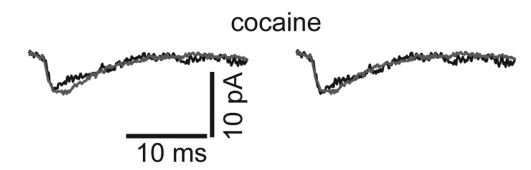

D

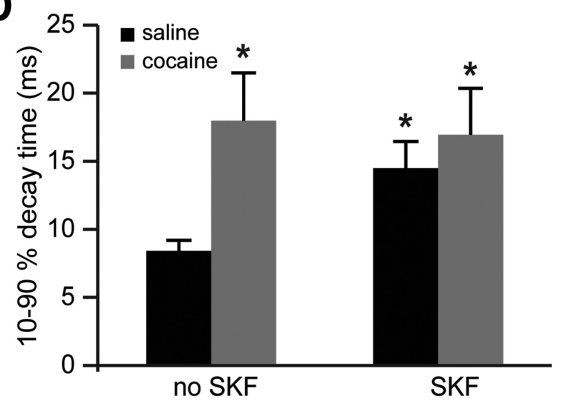

Figure 5. Blockade of glutamate reuptake reveals increased synaptic NMDA current duration following cocaine selfadministration and D1DR stimulation. $\boldsymbol{A}$, Left, NMDAR-mediated sEPSCs before (gray traces) and following (black traces) pretreatment of slices from saline controls with SKF38393. Right, The same traces are normalized to the peak amplitude to illustrate differences in the sEPSC decay time. $\boldsymbol{B}$, Same as in $\boldsymbol{A}$ but for slices from cocaine-experienced rats. $\boldsymbol{C}$, Bar histograms of mean NMDAR-mediated sEPSC amplitudes across the experimental groups. $\boldsymbol{D}$, Bar histograms summarizing differences in synaptic current duration (expressed as decay time from 90 to 10\% of the current peak). Again, notice that SKF38393 pretreatment is without effect in slices from cocaine-experienced rats $\left(t_{(11)}=2.68\right.$ for saline no SKF; $t_{(12)}=2.3$ for cocaine no SKF; $t_{(12)}=2.23$ for cocaine SKF; ${ }^{*} p<0.05$ vs nontreated saline; $n=6-8$ cells).

administration may arise due to differences in the efficiency of glutamate reuptake.

\section{Cocaine self-administration increases glutamate reuptake}

We evaluated the activity of glutamate reuptake transporters by measuring the effect of TBOA on baseline holding current. Application of TBOA elicited an inward shift of baseline current, reflecting accumulation of extracellular glutamate (Fig. $3 A$ ). If the increase in the NMDA charge transfer that we observe in slices from cocaine-experienced animals in the presence of TBOA is due to increased activity of glutamate uptake transporters, the magnitude of this shift should be larger in these slices. Indeed, our analyses revealed a $98 \%$ increase in TBOA-induced current in cocaine-treated animals, and that increase was not affected by SKF38393 treatment (Fig. 3A,B). Likewise, in slices from cocaine-naive controls, SKF38393 had no effect on TBOA-induced current
(Fig. 3A,B). Thus, SKF38393-induced potentiation of extrasynaptic NMDAR signaling in cocaine-naive animals was not due to differences in glutamate reuptake. In contrast, cocaine experience potentiated the activity of glutamate reuptake transporters and may have served to counteract the increase in NMDAR signaling.

\section{Glutamate spillover reveals increased extrasynaptic NMDAR signaling following cocaine exposure}

We next examined whether increased activity of extrasynaptic NMDARs contributes to the increase in NMDAR signaling in the presence of TBOA in cocaineexperienced animals. Tonic activation of NMDARs by ambient concentrations of extracellular glutamate recruits extrasynaptic pool of receptors (Sah et al., 1989; Le Meur et al., 2007; Papouin et al., 2012). Therefore, we recorded tonic NMDARmediated currents in the presence of TBOA as the amplitude of the outward shift of holding current in response to the application of the NMDAR antagonist DLAP5 $(50 \mu \mathrm{M})$. Tonic NMDAR-mediated current was increased following preexposure to SKF38393 in slices from yoked saline animals (Fig. 4A,B). Additionally, there was a significant increase of tonic current amplitude in slices from cocaine-experienced rats that was not markedly affected by SKF38393 pretreatment (Fig. 4A,B). These results suggest that increased glutamate reuptake masks the increased contribution of extrasynaptic NMDARs in slices from cocaineexperienced animals. Additionally, and as seen in previous experiments, slices from these animals are hyposensitive to the effects of D1DR stimulation.

We then extended our analyses to NMDAR-mediated sEPSCs recorded in the presence of TBOA. NMDARmediated sEPSCs were isolated by subtraction from sEPSCs mediated by both AMPA and NMDA receptors. We observed no differences in the amplitude of NMDA sEPSC among any of the conditions (Fig. 5A-C). However, the synaptic current duration (decay time) was significantly increased in the saline SKF group as well as in the cocaine group (Fig. 5D). Current decay time in the cocaine group was not significantly affected by SKF38393 pretreatment and remained elevated (Fig. 5D). The lack of differences in the peak NMDA sEPSC amplitude following blockade of glutamate reuptake replicates our eEPSC data obtained at minimal stimulation intensities (compare Fig. $1 B$ ). Other reports have attributed this lack of interaction between efficiency of glutamate transport and synaptic current amplitude to relatively high intrasynaptic concentration of glutamate, to relatively low intrasynaptic concentration of reuptake transporters, and to the background noise that increases in the presence of TBOA (Sarantis et al., 1993; 
A

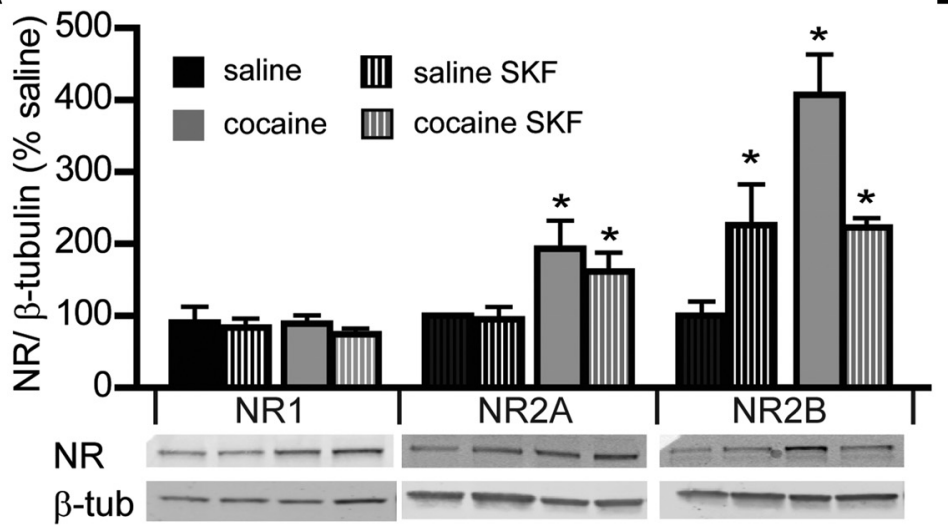

B

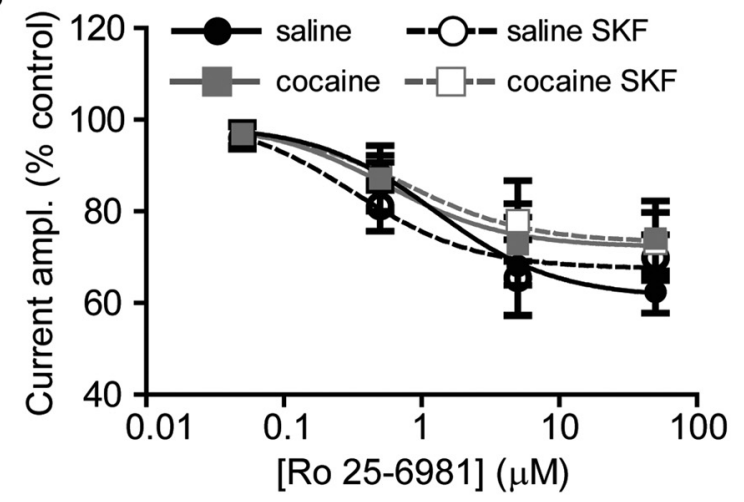

Figure 6. Increase in NR2B protein following D1DR stimulation and cocaine self-administration does not correspond to an increased contribution of NR2B to whole-cell NMDAR currents. $A$, Quantitative Western blot analyses of NMDAR subunit protein levels. Protein levels were examined in nucleus accumbens shell homogenates from five animals in each group $\left({ }^{*} p<0.05\right.$ vs nontreated saline, two-way ANOVA). B, Effects of NR2B antagonist, Ro 25-6981 (0.05, 0.5, 5, $\left.50 \mu \mathrm{m}\right)$, on currents evoked by whole-cell application of NMDA (100 $\left.\mu \mathrm{m}\right)$. For each neuron, the responses were normalized to currents evoked by NMDA in the absence of Ro 25-6981. Notice large variability in responses. There were no significant differences between groups ( $n=4-9$ cells at each concentration).

Zheng et al., 2008). The increase in decay time of synaptic current, meanwhile, could be expected from increased recruitment of extrasynaptic NMDARs by glutamate spillover or from a change in NMDAR subunit composition. For example, the presence of NR2B subunit is known to impart slow decay kinetics onto the assembled NMDAR tetramer (Vicini et al., 1998).

\section{Relative contribution of NR2B is not} altered by D1DR stimulation or cocaine experience

Experimenter-administered cocaine has been found to increase the expression of NR2B in the nucleus accumbens (Brown et al., 2011). Our finding of increased sEPSC decay time in animals trained to selfadminister cocaine appears consistent with this report. Therefore, we evaluated the expression of NMDAR subunit protein in the nucleus accumbens shell. The amount of the obligatory NR1 protein in the accumbens shell homogenates did not change following cocaine self-administration and was not affected by D1DR stimulation (Fig. 6A). However, the amount of both NR2A and NR2B subunits showed a significant increase following cocaine treatment, with NR2B levels declining following SKF38393 exposure. In slices from saline-treated controls, NR2A levels did not change following SKF38393 exposure. However, NR2B levels demonstrated a significant increase (Fig. $6 \mathrm{~A}$ ). If the increase in NR2B protein in the cocaine, cocaine SKF, and saline SKF groups corresponded to the increased expression of NR2B-containing receptors, we should observe an increase in sensitivity of NMDAR-mediated currents to the NR2B antagonist Ro 25-6981 (3 $\mu \mathrm{M})$. However, we observed equivalent Ro 25-6981-induced inhibition of whole-cell currents evoked by NMDA $(100 \mu \mathrm{M})$ across all treatment groups and a range of Ro 25-6981 concentrations (Fig. 6B). These results indicate that, although the contribution of extrasynaptic NMDARs increases following SKF38393 treatment and following cocaine treatment, functional expression of the NR2B subunit does not change.

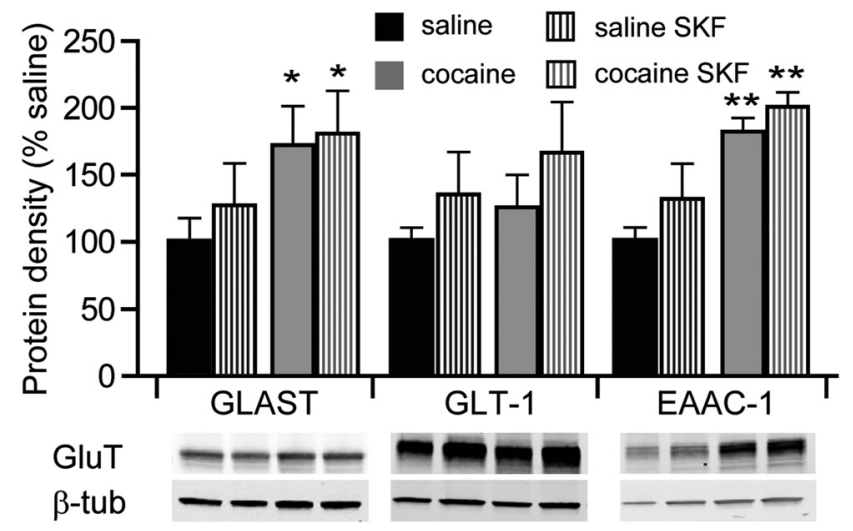

Figure 8. Expression of glutamate reuptake transporters. Quantitative Western blot analyses of protein levels of glutamate reuptake transporters (GluT), GLAST, GLT-1, and EAAC-1. Protein levels were examined in nucleus accumbens shell homogenates from five animals in each group. ${ }^{*} p<0.05,{ }^{* *} p<0.01$ vs nontreated saline, two-way ANOVA.

Glutamate uptake masks extrasynaptic NMDAR activation The results reported so far suggest that increased glutamate reuptake counteracts increased extrasynaptic NMDAR signaling in slices from cocaine-experienced animals. If this interpretation is correct, then, in the absence of glutamate reuptake blocker, tonic 
A

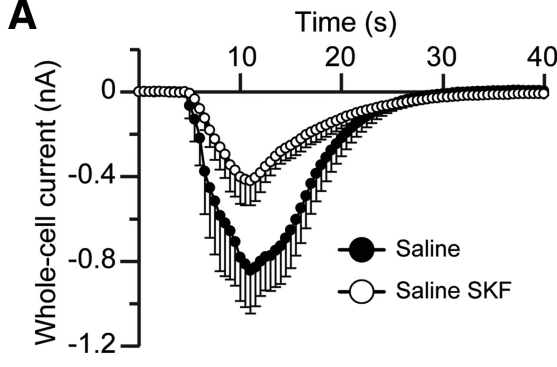

C

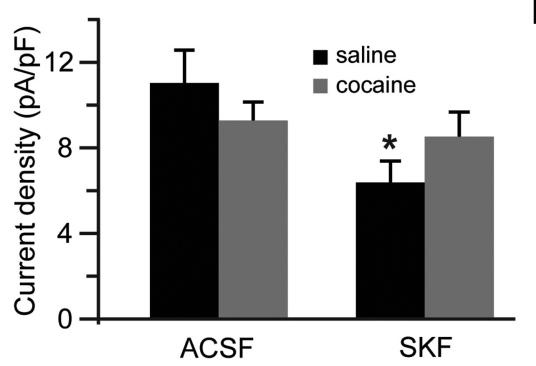

B

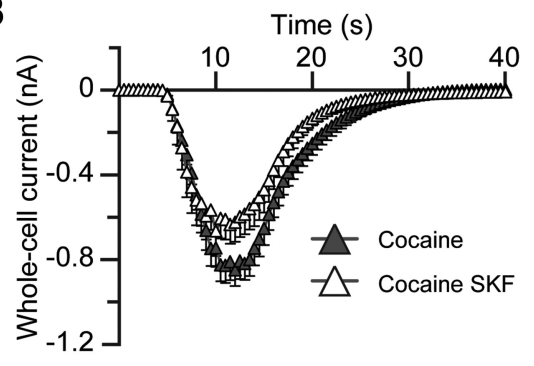

D

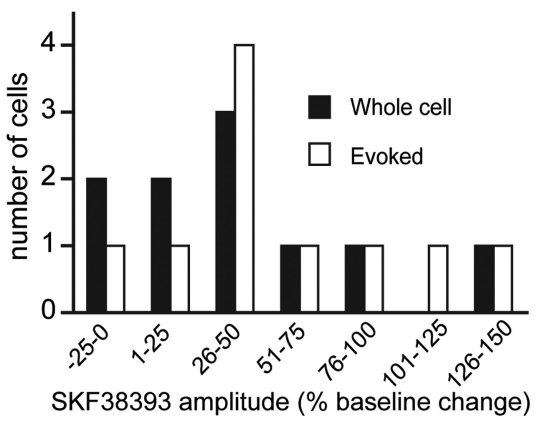

Figure 9. Chronic, but not acute, D1DR stimulation decreases NMDAR-mediated currents. $\boldsymbol{A}, \boldsymbol{B}$, Time course of whole-cell responses to NMDA (100 $\mu \mathrm{m}$ ) before and after pretreatment with SKF38393 in saline controls and cocaine-experienced animals. $C$, Summary histograms of whole-cell NMDA responses expressed as current density $\left(t_{(32)}=2.1 ;{ }^{*} p<0.05\right.$ vs nontreated saline; $n=$ 17-25 cells). D, A summary of eEPSCs (Evoked) and whole-cell NMDAR responses during acute application of SKF38393. In the majority of cells, NMDAR-mediated currents are potentiated during SKF38393 application.

currents mediated by extrasynaptic NMDARs should be similar between cocaine-experienced and cocaine-naive groups. Furthermore, stimulation of D1DRs under conditions of intact glutamate reuptake should increase tonic NMDAR currents in the saline SKF group, which does not show an adaptive increase of uptake transporter activity, but not in the cocaine and cocaine SKF groups, which do show such an increase. We examined the amplitude of tonic NMDAR current under these conditions and found that cocaine or cocaine SKF treatments did not affect the amplitude of tonic NMDAR currents. However, in the saline group, pretreatment with SKF38393 triggered a significant increase of tonic NMDAR currents (Fig. 7).

We next evaluated whether an apparent increase in glutamate reuptake in our electrophysiological studies corresponded to increased protein levels of glutamate transporters in the NAc shell. Glutamate reuptake in the CNS is driven by excitatory aminoacid transporters (EAAT) 1-5. Of these, EAAT1, EAAT2, and EAAT3 are the most abundant in the CNS and correspond to rodent homologues glutamate-aspartate transporter (GLAST), glutamate transporter 1 (GLT-1), and excitatory amino acid carrier 1 (EAAC-1), respectively. Our Western blot analyses indicated that exposure of cocaine-naive animals to SKF38393 did not significantly change the expression levels of these proteins (Fig. 8). However, in slices from cocaine-experienced animals, the expression of GLAST and EAAC-1, but not GLT-1, was significantly elevated compared with cocaine-naive animals, and was not further affected by treatment with SKF38393 (Fig. 8).

Altogether, these data lend further support to the assertion that, in slices from saline animals exposed to a D1DR agonist, cellular distribution of NMDARs is biased toward the extrasynaptic receptor population. Meanwhile, in slices from cocaineexperienced animals, contribution of extrasynaptic NMDAR population is limited by elevated glutamate reuptake and the resultant decrease in glutamate availability at extrasynaptic sites.

\section{Whole-cell levels of functional NMDARs}

Given the bimodal effects of SKF38393, characterized by a decrease of synaptic NMDAR-mediated currents, but an increase of extrasynaptic NMDAR-mediated currents, in cocaine-naive animals, we wanted to examine the overall level of functional NMDARs in these cells. There was a significant decrease of whole-cell responses to NMDA $(100 \mu \mathrm{M})$ in cells from cocainenaive animals treated with SKF38393. A small decrease of whole-cell responses to NMDA in cells from animals with cocaine history treated with SKF38393 failed to reach statistical significance (Fig. 9A,B). These differences were reflected in NMDAR-mediated current densities (Fig. 9C). The decreases in whole-cell responses to NMDA that we observed following SKF38393 exposure run contrary to the reported ability of D1DRs to potentiate whole-cell responses to NMDA (Cepeda et al., 1993; Harvey and Lacey, 1997; Cepeda and Levine, 1998; Chergui and Lacey, 1999; Flores-Hernández et al., 2002; but see Beurrier and Malenka, 2002). Such potentiation was observed in response to acute stimulation of D1DRs, whereas our effects represent effects on NMDAR currents that persist in the absence of acute pharmacological effects of D1DR activation. To verify the distinction between chronic and acute effects of D1DR stimulation on NMDAR currents, we examined whole-cell and evoked NMDAR responses during acute application of SKF38393. Our results were similar to those of Chergui and Lacey (1999) and Cepeda et al. (1993) with the majority of the cells showing potentiation of both whole-cell and evoked NMDAR currents and a small fraction of cells exhibiting no effect or a depression of peak amplitude during the SKF38393 application (Fig. 9D).

\section{Discussion}

Our results demonstrated that stimulation of accumbens shell D1DRs in yoked saline rats resulted in increased extrasynaptic NMDAR signaling. This was accompanied by a reduction in synaptic NMDAR-mediated currents and was not associated with an increased contribution of NR2B-containing NMDARs. Cocaine self-administration also increased signaling at extrasynaptic NMDARs without affecting the NR2B contribution. However, this increase was not accompanied by reduced synaptic NMDAR efficacy. Instead, cocaine-experience was associated with increased expression and activity of glutamate reuptake transporters that masked increased signaling at extrasynaptic NMDARs. These findings outline a pattern of adaptive interactions between D1DRs and NMDARs in the nucleus accumbens shell triggered by D1DR stimulation and by self-administered cocaine.

\section{Effects of D1DR stimulation on NMDAR expression and signaling}

Our analyses showed increased expression of NR2A and NR2B, but not of NR1 subunits, $24 \mathrm{~h}$ following the last cocaine selfadministration session. The increase in NR1 protein is not necessary for an increase in the expression of functional NMDA channels, since NR1 subunits are expressed in excess of NR2 
subunits (Wenthold et al., 2003). However, the increase in NR2 levels did not correspond to an increase in NMDAR function either, since whole-cell responses to NMDA in cocaineexperienced animals were not statistically different from responses in their cocaine-naive counterparts. Similarly, cocaine experience did not influence tonic or synaptic NMDARmediated currents under normal recording conditions. These results are consistent with another study that found unaltered $\left[{ }^{3} \mathrm{H}\right] \mathrm{MK}-801$ binding to NMDARs in the nucleus accumbens following brief and extended withdrawal from cocaine selfadministration (Ben-Shahar et al., 2007).

The effects of D1DR stimulation on the expression of NMDARs have been examined by a number of groups. Thus, activation of D1DRs in HEK-293 cells coexpressing D1, NR1, and NR2A or NR2B subunits reduced NMDAR responses and led to NMDAR internalization (Lee et al., 2002; Fiorentini et al., 2003; $\mathrm{Gu}$ et al., 2007). Reduced synaptic and whole-cell NMDARmediated currents following SKF38393 pretreatment of cocainenaive slices, which we observed, is consistent with these results. Notably, protein-protein interactions between D1DR and NMDAR have been shown to decrease the amplitude of NMDAR-mediated currents (Lee et al., 2002). Sensitivity of D1DR-NMDAR dimers to D1DR stimulation may vary depending on synaptic or extrasynaptic localization of D1DRs (Dumartin et al., 1998) and may have contributed to our findings. It is interesting that in a membrane fractionation study involving striatal tissue homogenates, activation of D1DRs triggered redistribution of NR1, NR2A, and NR2B to synaptosomal compartments (Dunah et al., 2004), suggesting increased synaptic incorporation of these subunits. Surface expression of NR1 and NR2B protein also was reported to increase following exposure of cultured prefrontal cortex neurons to a D1DR agonist (Gao and Wolf, 2008; Hu et al., 2010). In partial similarity to these reports, we observed an increase in NR2B subunit protein, but not NR1 or NR2A subunit protein, in accumbens shell homogenates from yoked saline rats treated with SKF38393. However, our patch-clamp experiments suggest that protein levels as measured by Western blot do not necessarily reflect incorporation of functional receptors into the cell membrane.

A large literature focuses on the consequences of cocaine treatment on NMDAR subunit expression. Following noncontingent administration of cocaine, the majority of evidence indicates that mRNA and protein levels of NMDARs in the nucleus accumbens are not changed in early abstinence $(\leq 24 \mathrm{~h})$, but are increased at weeks or longer intervals of abstinence from cocaine or following extinction of cocaine-seeking (Ghasemzadeh et al., 1999, 2009; Crespo et al., 2002; Schumann and Yaka, 2009; Yamamoto and Zahniser, 2012). Some studies, however, find that noncontingent cocaine administration decreases the expression of NMDAR subunits in the nucleus accumbens (Loftis and Janowsky, 2000; Le Greves et al., 2002). The pattern of decreased to increased expression of NMDAR with abstinence from noncontingent cocaine appears to be reversed following cocaine selfadministration. NMDA subunit mRNA and protein levels increase following self-administered cocaine and decline following extinction of cocaine-seeking (Crespo et al., 2002), but not following withdrawal from self-administered cocaine (Lu et al., 2003; but see Self et al., 2004). Our findings of increased NR2A and NR2B levels parallel these reports. However, we find that these increases are not accompanied by an overall increase in NMDAR-mediated signaling measured by whole-cell responses to NMDA.

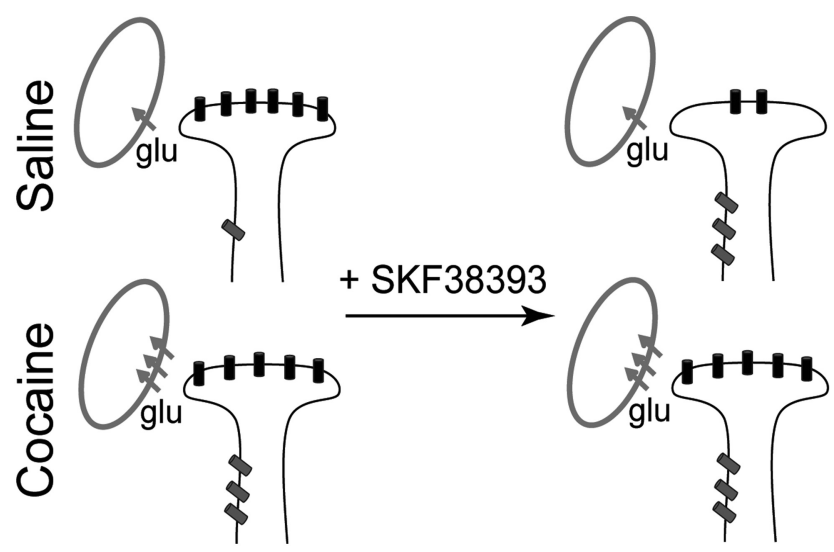

Figure 10. Cocaine experience and D1DR stimulation alter the balance between synaptic and extrasynaptic NMDAR-mediated signaling. A working model summarizing changes in relative contributions of synaptic (black) and extrasynaptic (gray) NMDARs. Following cocaine experience, an increased contribution of extrasynaptic NMDAR receptors is masked by elevated glutamate reuptake. D1DR stimulation has no effect on NMDAR-mediated currents in this group. In saline controls, D1DR stimulation is sufficient to induce an increase in extrasynaptic NMDAR-mediated signaling. This is accompanied by a reduction of synaptic NMDAR signaling and occurs in the absence of changes in glutamate reuptake. Note that for the purposes of this diagram, glutamate reuptake occurs at unspecified (either glial or neuronal) sites.

\section{Regulation of synaptic and extrasynaptic NMDAR by D1DRs}

The current results indicated that stimulation of D1DRs had a bimodal effect on currents mediated by synaptic and extrasynaptic NMDARs in cocaine-naive animals. Evoked EPSCs, mediated by synaptic NMDARs, were reduced, whereas activation of extrasynaptic NMDARs examined in tonic and MK-801 experiments increased. Together with a reduction in whole-cell NMDARmediated currents, these findings suggest that endocytosis or dispersal of NMDA channels from synaptic membranes is coupled with accumulation of NMDARs at extrasynaptic sites. Along these lines, redistribution of NMDARs away from synaptic sites in striatal medium spiny and hippocampal neurons has been reported following protein kinase $\mathrm{C}$ (PKC) activation (Fong et al., 2002; Groc et al., 2004). Interestingly, D1DR-mediated internalization of NMDARs that may underlie reduced wholecell currents that we observe was shown to be independent of both protein kinase A (PKA) and PKC signaling (Lee et al., 2002). These reports diverge from the canonical association of D1DRs with activation of PKA. However, the importance of D1DR coupling to activation of other kinases, including PKC and Src family kinases, is increasingly recognized, particularly with regard to regulation of NMDAR expression and function (Chergui and Lacey, 1999; Tong and Gibb, 2008; Sarantis et al., 2009; Hu et al., 2010; Li et al., 2010; Ren et al., 2010). It is, therefore, feasible that the reduced whole-cell and synaptic NMDAR currents and increased extrasynaptic NMDAR-mediated responses in our study are a consequence of D1DR coupling to transduction cascades that do not include PKA.

Another relevant point has to do with the potentially distinct effects of D1DR stimulation on MSNs of the direct (D1DRexpressing) and indirect (D2DR-expressing) pathways. In a subset of experiments, we attempted to distinguish between these two populations by measuring input resistance and rheobase. These measures have been reported to effectively discriminate between the D1DR and D2DR MSNs (Gertler et al., 2008; Janssen et al., 2009). Although we too found input resistance and rheobase to be bimodally distributed in our sample of cells, we did not observe a correlation between these measures and the magnitude 
of whole-cell responses to NMDA or the relative contribution of extrasynaptic NMDA receptors (data not shown). D1DR and D2DRs can be coexpressed in accumbal neurons (Surmeier et al., 1992; Lu et al., 1998). Moreover, while low levels of D1DR expression in indirect pathway neurons or D2DR expression in direct pathway neurons require highly sensitive visualization techniques, such low levels of expression are sufficient for functional responses to selective dopamine receptor agonists (Aizman et al., 2000).

\section{Role of NMDAR subunits}

The results of several studies indicated that extrasynaptic NMDARs are composed predominantly of NR1/NR2B complexes (Stocca and Vicini, 1998; Tovar and Westbrook, 1999). However, other investigations argued that NR1/NR2A and NR1/ NR2B complexes contribute to both synaptic and extrasynaptic pools of NMDARs, especially at later neurodevelopmental stages (Rumbaugh and Vicini, 1999; Misra et al., 2000; Mohrmann et al., 2000; Thomas et al., 2006; Harris and Pettit, 2007; Miwa et al., 2008; Petralia et al., 2010). Our results support this larger literature and further indicate that the contribution of NR2Bcontaining NMDARs to NMDAR-mediated currents does not change following D1DR stimulation and is not affected by cocaine self-administration. Therefore, increases in currents mediated by extrasynaptic NMDARs in saline SKF slices and in TBOA-exposed cocaine slices are likely mediated by receptors containing both NR2A and NR2B. Notably, although the expression of NR2C and NR2D subunits is prominent in interneurons of dorsal and ventral striatum, neither subunit is present in striatal MSNs (Bloomfield et al., 2007). Since our recordings were exclusively from MSNs, NMDARs incorporating these subunits are unlikely to have contributed to the results.

\section{Regulation of NMDAR signaling by glutamate reuptake}

Our results showed that cocaine experience, but not SKF38393 treatment, is associated with increased expression of glutamate reuptake transporters GLAST and EAAC-1, but not GLT-1. GLAST and GLT-1 are expressed predominantly in glial cells, while EAAC-1 expression is largely neuronal. Since TBOA does not discriminate between transporter subtypes, our results suggest that both neuronal and glial glutamate reuptake may have contributed to the increase in tonic current induced by TBOA as well as the TBOA-induced increase of NMDAR-mediated synaptic charge. Furthermore, the lack of differences in GLT-1 expression that we observe is similar to a previous report examining GLT-1 levels after $1 \mathrm{~d}$ of abstinence from short access $(2 \mathrm{~h} / \mathrm{d})$ cocaine self-administration (Fischer-Smith et al., 2012). It is worth noting that, although $>90 \%$ of the total glutamate uptake occurs via the glial transporters (Rothstein et al., 1996; Tanaka et al., 1997), NMDAR signaling has been shown to be more influenced by neuronal rather than glial glutamate reuptake (Diamond, 2001; Scimemi et al., 2009). Nevertheless, given the increase in GLAST protein levels and the possibility that changes in GLT-1 expression could fall below the limits of detection, we cannot exclude regulation of NMDAR activity by glial reuptake transporters in our preparation. We conclude that in early abstinence from short-access cocaine self-administration, upregulation of glutamate reuptake through individual or combined contribution of glial and neuronal transporters masks the increase in currents mediated by extrasynaptic NMDARs.

\section{Conclusions}

Our results demonstrate that stimulation of D1DRs in the nucleus accumbens decreases NMDAR responses to phasic synaptic stimulation, but increases tonic signaling through NMDARs located at extrasynaptic sites. Cocaine self-administration has no effect on synaptic NMDAR-mediated currents, but increases extrasynaptic NMDAR signaling and blunts sensitivity of nucleus accumbens neurons to D1DR stimulation. In cocaine-experienced rats, increased signaling via tonically active NMDARs occurs in conjunction with increased glutamate reuptake (Fig. 10), which may contribute to reduced extracellular glutamate concentrations in these animals, as reported previously (Pierce et al., 1996; McFarland et al., 2003; Miguéns et al., 2008). The pattern of increased glutamate reuptake accompanied by an increase in extrasynaptic NMDAR signaling highlights an adaptive consequence of cocaine selfadministration that maintains the homeostatic balance between phasic and tonic glutamate signals in the nucleus accumbens.

\section{References}

Aizman O, Brismar H, Uhlén P, Zettergren E, Levey AI, Forssberg H, Greengard P, Aperia A (2000) Anatomical and physiological evidence for D1 and D2 dopamine receptor colocalization in neostriatal neurons. Nat Neurosci 3:226-230. CrossRef Medline

Ben-Shahar O, Keeley P, Cook M, Brake W, Joyce M, Nyffeler M, Heston R, Ettenberg A (2007) Changes in levels of D1, D2, or NMDA receptors during withdrawal from brief or extended daily access to IV cocaine. Brain Res 1131:220-228. CrossRef Medline

Beurrier C, Malenka RC (2002) Enhanced inhibition of synaptic transmission by dopamine in the nucleus accumbens during behavioral sensitization to cocaine. J Neurosci 22:5817-5822. Medline

Beutler LR, Wanat MJ, Quintana A, Sanz E, Bamford NS, Zweifel LS, Palmiter RD (2011) Balanced NMDA receptor activity in dopamine D1 receptor (D1R) - and D2R-expressing medium spiny neurons is required for amphetamine sensitization. Proc Natl Acad Sci U S A 108:4206-4211. CrossRef Medline

Bloomfield C, O’Donnell P, French SJ, Totterdell S (2007) Cholinergic neurons of the adult rat striatum are immunoreactive for glutamatergic $\mathrm{N}$-methyl-d-aspartate $2 \mathrm{D}$ but not $\mathrm{N}$-methyl-d-aspartate $2 \mathrm{C}$ receptor subunits. Neuroscience 150:639-646. CrossRef Medline

Brown TE, Lee BR, Mu P, Ferguson D, Dietz D, Ohnishi YN, Lin Y, Suska A, Ishikawa M, Huang YH, Shen H, Kalivas PW, Sorg BA, Zukin RS, Nestler EJ, Dong Y, Schlüter OM (2011) A silent synapse-based mechanism for cocaine-induced locomotor sensitization. J Neurosci 31:8163-8174. CrossRef Medline

Cepeda C, Levine MS (1998) Dopamine and N-methyl-D-aspartate receptor interactions in the neostriatum. Dev Neurosci 20:1-18. CrossRef Medline

Cepeda C, Buchwald NA, Levine MS (1993) Neuromodulatory actions of dopamine in the neostriatum are dependent upon the excitatory amino acid receptor subtypes activated. Proc Natl Acad Sci U S A 90:9576-9580. CrossRef Medline

Chalifoux JR, Carter AG (2011) Glutamate spillover promotes the generation of NMDA spikes. J Neurosci 31:16435-16446. CrossRef Medline

Chergui K, Lacey MG (1999) Modulation by dopamine D1-like receptors of synaptic transmission and NMDA receptors in rat nucleus accumbens is attenuated by the protein kinase $\mathrm{C}$ inhibitor Ro 32-0432. Neuropharmacology 38:223-231. CrossRef Medline

Cornish JL, Kalivas PW (2000) Glutamate transmission in the nucleus accumbens mediates relapse in cocaine addiction. J Neurosci 20:RC89. Medline

Cornish JL, Duffy P, Kalivas PW (1999) A role for nucleus accumbens glutamate transmission in the relapse to cocaine-seeking behavior. Neuroscience 93:1359-1367. CrossRef Medline

Crespo JA, Oliva JM, Ghasemzadeh MB, Kalivas PW, Ambrosio E (2002) Neuroadaptive changes in NMDAR1 gene expression after extinction of cocaine self-administration. Ann N Y Acad Sci 965:78-91. Medline

De Vries TJ, Schoffelmeer AN, Binnekade R, Mulder AH, Vanderschuren LJ (1998) MK-801 reinstates drug-seeking behaviour in cocaine-trained rats. Neuroreport 9:637-640. CrossRef Medline

Diamond JS (2001) Neuronal glutamate transporters limit activation of 
NMDA receptors by neurotransmitter spillover on CA1 pyramidal cells. J Neurosci 21:8328-8338. Medline

Dudman JT, Eaton ME, Rajadhyaksha A, Macías W, Taher M, Barczak A, Kameyama K, Huganir R, Konradi C (2003) Dopamine D1 receptors mediate CREB phosphorylation via phosphorylation of the NMDA receptor at Ser897-NR1. J Neurochem 87:922-934. Medline

Dumartin B, Caill é I, Gonon F, Bloch B (1998) Internalization of D1 dopamine receptor in striatal neurons in vivo as evidence of activation by dopamine agonists. J Neurosci 18:1650-1661. Medline

Dunah AW, Sirianni AC, Fienberg AA, Bastia E, Schwarzschild MA, Standaert DG (2004) Dopamine D1-dependent trafficking of striatal N-methylD-aspartate glutamate receptors requires Fyn protein tyrosine kinase but not DARPP-32. Mol Pharmacol 65:121-129. CrossRef Medline

Famous KR, Schmidt HD, Pierce RC (2007) When administered into the nucleus accumbens core or shell, the NMDA receptor antagonist AP-5 reinstates cocaine-seeking behavior in the rat. Neurosci Lett 420:169-173. CrossRef Medline

Fiorentini C, Gardoni F, Spano P, Di Luca M, Missale C (2003) Regulation of dopamine D1 receptor trafficking and desensitization by oligomerization with glutamate N-methyl-D-aspartate receptors. J Biol Chem 278: 20196-20202. CrossRef Medline

Fischer-Smith KD, Houston AC, Rebec GV (2012) Differential effects of cocaine access and withdrawal on glutamate type 1 transporter expression in rat nucleus accumbens core and shell. Neuroscience 210:333-339. CrossRef Medline

Flores-Hernández J, Cepeda C, Hernández-Echeagaray E, Calvert CR, Jokel ES, Fienberg AA, Greengard P, Levine MS (2002) Dopamine enhancement of NMDA currents in dissociated medium-sized striatal neurons: role of D1 receptors and DARPP-32. J Neurophysiol 88:3010-3020. CrossRef Medline

Fong DK, Rao A, Crump FT, Craig AM (2002) Rapid synaptic remodeling by protein kinase C: reciprocal translocation of NMDA receptors and calcium/calmodulin-dependent kinase II. J Neurosci 22:2153-2164. Medline

Gao C, Wolf ME (2008) Dopamine receptors regulate NMDA receptor surface expression in prefrontal cortex neurons. J Neurochem 106:24892501. CrossRef Medline

Gertler TS, Chan CS, Surmeier DJ (2008) Dichotomous anatomical properties of adult striatal medium spiny neurons. J Neurosci 28:1081410824. CrossRef Medline

Ghasemzadeh MB, Nelson LC, Lu XY, Kalivas PW (1999) Neuroadaptations in ionotropic and metabotropic glutamate receptor mRNA produced by cocaine treatment. J Neurochem 72:157-165. Medline

Ghasemzadeh MB, Mueller C, Vasudevan P (2009) Behavioral sensitization to cocaine is associated with increased glutamate receptor trafficking to the postsynaptic density after extended withdrawal period. Neuroscience 159:414-426. CrossRef Medline

Gladding CM, Raymond LA (2011) Mechanisms underlying NMDA receptor synaptic/extrasynaptic distribution and function. Mol Cell Neurosci 48:308-320. CrossRef Medline

Groc L, Heine M, Cognet L, Brickley K, Stephenson FA, Lounis B, Choquet D (2004) Differential activity-dependent regulation of the lateral mobilities of AMPA and NMDA receptors. Nat Neurosci 7:695-696. CrossRef Medline

Gu WH, Yang S, Shi WX, Jin GZ, Zhen XC (2007) Requirement of PSD-95 for dopamine D1 receptor modulating glutamate NR1a/NR2B receptor function. Acta Pharmacol Sin 28:756-762. CrossRef Medline

Hanson GR, Singh N, Merchant K, Johnson M, Gibb JW (1995) The role of NMDA receptor systems in neuropeptide responses to stimulants of abuse. Drug Alcohol Depend 37:107-110. CrossRef Medline

Hardingham GE, Fukunaga Y, Bading H (2002) Extrasynaptic NMDARs oppose synaptic NMDARs by triggering CREB shut-off and cell death pathways. Nat Neurosci 5:405-414. Medline

Harris AZ, Pettit DL (2007) Extrasynaptic and synaptic NMDA receptors form stable and uniform pools in rat hippocampal slices. J Physiol 584: 509-519. CrossRef Medline

Harvey J, Lacey MG (1997) A postsynaptic interaction between dopamine D1 and NMDA receptors promotes presynaptic inhibition in the rat nucleus accumbens via adenosine release. J Neurosci 17:5271-5280. Medline

Heusner CL, Palmiter RD (2005) Expression of mutant NMDA receptors in dopamine D1 receptor-containing cells prevents cocaine sensitization and decreases cocaine preference. J Neurosci 25:6651-6657. CrossRef Medline

Hevers W, Lüddens H (2002) Pharmacological heterogeneity of gammaaminobutyric acid receptors during development suggests distinct classes of rat cerebellar granule cells in situ. Neuropharmacology 42:34-47. CrossRef Medline

Hu JL, Liu G, Li YC, Gao WJ, Huang YQ (2010) Dopamine D1 receptormediated NMDA receptor insertion depends on Fyn but not Src kinase pathway in prefrontal cortical neurons. Molecular Brain 3:20. CrossRef Medline

Huang YH, Lin Y, Mu P, Lee BR, Brown TE, Wayman G, Marie H, Liu W, Yan Z, Sorg BA, Schlüter OM, Zukin RS, Dong Y (2009) In vivo cocaine experience generates silent synapses. Neuron 63:40-47. CrossRef Medline

Huettner JE, Bean BP (1988) Block of N-methyl-D-aspartate-activated current by the anticonvulsant MK-801: selective binding to open channels. Proc Natl Acad Sci U S A 85:1307-1311. CrossRef Medline

Janssen MJ, Ade KK, Fu Z, Vicini S (2009) Dopamine modulation of GABA tonic conductance in striatal output neurons. J Neurosci 29:5116-5126. CrossRef Medline

Johansen PA, Hu XT, White FJ (1991) Relationship between D1 dopamine receptors, adenylate cyclase, and the electrophysiological responses of rat nucleus accumbens neurons. J Neural Transm Gen Sect 86:97-113. CrossRef Medline

Kervern M, Angeli A, Nicole O, Léveillé F, Parent B, Villette V, Buisson A, Dutar P (2012) Selective impairment of some forms of synaptic plasticity by oligomeric amyloid-beta peptide in the mouse hippocampus: implication of extrasynaptic NMDA receptors. J Alzheimers Dis 32:183-196. Medline

Komuro H, Rakic P (1993) Modulation of neuronal migration by NMDA receptors. Science 260:95-97. CrossRef Medline

Lau CG, Zukin RS (2007) NMDA receptor trafficking in synaptic plasticity and neuropsychiatric disorders. Nat Rev Neuroscience 8:413-426. CrossRef Medline

Lee DK, Ahn SM, Shim YB, Koh WC, Shim I, Choe ES (2011) Interactions of dopamine D1 and N-methyl-D-Aspartate receptors are required for acute cocaine-evoked nitric oxide efflux in the dorsal striatum. Exp Neurobiol 20:116-122. CrossRef Medline

Lee FJ, Xue S, Pei L, Vukusic B, Chéry N, Wang Y, Wang YT, Niznik HB, Yu XM, Liu F (2002) Dual regulation of NMDA receptor functions by direct protein-protein interactions with the dopamine D1 receptor. Cell 111:219-230. CrossRef Medline

Le Greves P, Zhou Q, Huang W, Nyberg F (2002) Effect of combined treatment with nandrolone and cocaine on the NMDA receptor gene expression in the rat nucleus accumbens and periaqueductal gray. Acta Psychiatr Scand Suppl:129-132. Medline

Le Meur K, Galante M, Angulo MC, Audinat E (2007) Tonic activation of NMDA receptors by ambient glutamate of nonsynaptic origin in the rat hippocampus. J Physiol 580:373-383. Medline

Léveillé F, El Gaamouch F, Gouix E, Lecocq M, Lobner D, Nicole O, Buisson A (2008) Neuronal viability is controlled by a functional relation between synaptic and extrasynaptic NMDA receptors. FASEB J 22:42584271. CrossRef Medline

Li YC, Liu G, Hu JL, Gao WJ, Huang YQ (2010) Dopamine D1 receptormediated enhancement of NMDA receptor trafficking requires rapid PKC-dependent synaptic insertion in the prefrontal neurons. J Neurochem 114:62-73. CrossRef Medline

Loftis JM, Janowsky A (2000) Regulation of NMDA receptor subunits and nitric oxide synthase expression during cocaine withdrawal. J Neurochem 75:2040-2050. Medline

Lozovaya NA, Grebenyuk SE, Tsintsadze TSh, Feng B, Monaghan DT, Krishtal OA (2004) Extrasynaptic NR2B and NR2D subunits of NMDA receptors shape 'superslow' afterburst EPSC in rat hippocampus. J Physiol 558:451-463. CrossRef Medline

Lu L, Grimm JW, Shaham Y, Hope BT (2003) Molecular neuroadaptations in the accumbens and ventral tegmental area during the first $90 \mathrm{ds}$ of forced abstinence from cocaine self-administration in rats. J Neurochem 85:1604-1613. CrossRef Medline

Lu XY, Ghasemzadeh MB, Kalivas PW (1998) Expression of D1 receptor, $D 2$ receptor, substance $P$ and enkephalin messenger RNAs in the neurons projecting from the nucleus accumbens. Neuroscience 82:767-780. Medline 
McFarland K, Lapish CC, Kalivas PW (2003) Prefrontal glutamate release into the core of the nucleus accumbens mediates cocaine-induced reinstatement of drug-seeking behavior. J Neurosci 23:3531-3537. Medline

Miguéns M, Del Olmo N, Higuera-Matas A, Torres I, García-Lecumberri C, Ambrosio E (2008) Glutamate and aspartate levels in the nucleus accumbens during cocaine self-administration and extinction: a time course microdialysis study. Psychopharmacology (Berl) 196:303-313. Medline

Misra C, Brickley SG, Farrant M, Cull-Candy SG (2000) Identification of subunits contributing to synaptic and extrasynaptic NMDA receptors in Golgi cells of the rat cerebellum. J Physiol 524:147-162. CrossRef Medline

Miwa H, Fukaya M, Watabe AM, Watanabe M, Manabe T (2008) Functional contributions of synaptically localized NR2B subunits of the NMDA receptor to synaptic transmission and long-term potentiation in the adult mouse CNS. J Physiol 586:2539-2550. CrossRef Medline

Mohrmann R, Hatt H, Gottmann K (2000) Developmental regulation of subunit composition of extrasynaptic NMDA receptors in neocortical neurones. Neuroreport 11:1203-1208. CrossRef Medline

Murase K, Ryu PD, Randic M (1989) Excitatory and inhibitory amino acids and peptide-induced responses in acutely isolated rat spinal dorsal horn neurons. Neurosci Lett 103:56-63. Medline

Ortinski PI, Vassoler FM, Carlson GC, Pierce RC (2012) Temporally dependent changes in cocaine-induced synaptic plasticity in the nucleus accumbens shell are reversed by D1-like dopamine receptor stimulation. Neuropsychopharmacology 37:1671-1682. CrossRef Medline

Papouin T, Ladépêche L, Ruel J, Sacchi S, Labasque M, Hanini M, Groc L, Pollegioni L, Mothet JP, Oliet SH (2012) Synaptic and extrasynaptic NMDA receptors are gated by different endogenous coagonists. Cell 150: 633-646. CrossRef Medline

Parada A, Soares-da-Silva P (2000) The dopamine antagonist sch 23390 reverses dizocilpine-induced blockade of cocaine sensitization. Neuropharmacology 39:1645-1652. CrossRef Medline

Park WK, Bari AA, Jey AR, Anderson SM, Spealman RD, Rowlett JK, Pierce RC (2002) Cocaine administered into the medial prefrontal cortex reinstates cocaine-seeking behavior by increasing AMPA receptor-mediated glutamate transmission in the nucleus accumbens. J Neurosci 22:2916-2925. Medline

Petralia RS (2012) Distribution of extrasynaptic NMDA receptors on neurons. ScientificWorldJournal 2012:267120. CrossRef Medline

Petralia RS, Wang YX, Hua F, Yi Z, Zhou A, Ge L, Stephenson FA, Wenthold RJ (2010) Organization of NMDA receptors at extrasynaptic locations. Neuroscience 167:68-87. CrossRef Medline

Pierce RC, Bell K, Duffy P, Kalivas PW (1996) Repeated cocaine augments excitatory amino acid transmission in the nucleus accumbens only in rats having developed behavioral sensitization. J Neurosci 16:1550-1560. Medline

Portugal GS, Wilkinson DS, Turner JR, Blendy JA, Gould TJ (2012) Developmental effects of acute, chronic, and withdrawal from chronic nicotine on fear conditioning. Neurobiol Learn Mem 97:482-494. CrossRef Medline

Pulvirenti L, Swerdlow NR, Koob GF (1991) Nucleus accumbens NMDA antagonist decreases locomotor activity produced by cocaine, heroin or accumbens dopamine, but not caffeine. Pharmacol Biochem Behav 40: 841-845. Medline

Pulvirenti L, Maldonado-Lopez R, Koob GF (1992) NMDA receptors in the nucleus accumbens modulate intravenous cocaine but not heroin selfadministration in the rat. Brain Res 594:327-330. Medline

Ren Z, Sun WL, Jiao H, Zhang D, Kong H, Wang X, Xu M (2010) Dopamine $\mathrm{D} 1$ and $\mathrm{N}$-methyl-d-aspartate receptors and extracellular signalregulated kinase mediate neuronal morphological changes induced by repeated cocaine administration. Neuroscience 168:48-60. CrossRef Medline

Rothstein JD, Dykes-Hoberg M, Pardo CA, Bristol LA, Jin L, Kuncl RW, Kanai Y, Hediger MA, Wang Y, Schielke JP, Welty DF (1996) Knockout of glutamate transporters reveals a major role for astroglial transport in excitotoxicity and clearance of glutamate. Neuron 16:675-686. CrossRef Medline

Rumbaugh G, Vicini S (1999) Distinct synaptic and extrasynaptic NMDA receptors in developing cerebellar granule neurons. J Neurosci 19:1060310610. Medline

Ryman-Rasmussen JP, Nichols DE, Mailman RB (2005) Differential activa- tion of adenylate cyclase and receptor internalization by novel dopamine D1 receptor agonists. Mol Pharmacol 68:1039-1048. Medline

Sah P, Hestrin S, Nicoll RA (1989) Tonic activation of NMDA receptors by ambient glutamate enhances excitability of neurons. Science 246 : 815-818. CrossRef Medline

Sarantis K, Matsokis N, Angelatou F (2009) Synergistic interactions of dopamine D1 and glutamate NMDA receptors in rat hippocampus and prefrontal cortex: involvement of ERK1/2 signaling. Neuroscience 163: 1135-1145. CrossRef Medline

Sarantis M, Ballerini L, Miller B, Silver RA, Edwards M, Attwell D (1993) Glutamate uptake from the synaptic cleft does not shape the decay of the nonNMDA component of the synaptic current. Neuron 11:541-549. CrossRef Medline

Schenk S, Valadez A, Worley CM, McNamara C (1993) Blockade of the acquisition of cocaine self-administration by the NMDA antagonist MK801 (dizocilpine). Behav Pharmacol 4:652-659. Medline

Schilström B, Yaka R, Argilli E, Suvarna N, Schumann J, Chen BT, Carman M, Singh V, Mailliard WS, Ron D, Bonci A (2006) Cocaine enhances NMDA receptor-mediated currents in ventral tegmental area cells via dopamine D5 receptor-dependent redistribution of NMDA receptors. J Neurosci 26:8549-8558. CrossRef Medline

Schmidt HD, Pierce RC (2010) Cocaine-induced neuroadaptations in glutamate transmission: potential therapeutic targets for craving and addiction. Ann N Y Acad Sci 1187:35-75. CrossRef Medline

Schumann J, Yaka R (2009) Prolonged withdrawal from repeated noncontingent cocaine exposure increases NMDA receptor expression and ERK activity in the nucleus accumbens. J Neurosci 29:6955-6963. CrossRef Medline

Scimemi A, Fine A, Kullmann DM, Rusakov DA (2004) NR2B-containing receptors mediate cross talk among hippocampal synapses. J Neurosci 24:4767-4777. CrossRef Medline

Scimemi A, Tian H, Diamond JS (2009) Neuronal transporters regulate glutamate clearance, NMDA receptor activation, and synaptic plasticity in the hippocampus. J Neurosci 29:14581-14595. CrossRef Medline

Self DW, Choi KH, Simmons D, Walker JR, Smagula CS (2004) Extinction training regulates neuroadaptive responses to withdrawal from chronic cocaine self-administration. Learn Memory 11:648-657. CrossRef Medline

Stocca G, Vicini S (1998) Increased contribution of NR2A subunit to synaptic NMDA receptors in developing rat cortical neurons. J Physiol 507: 13-24. CrossRef Medline

Sun W-L, Zhou L, Quinones-Jenab V, Jenab S (2009) Cocaine effects on dopamine and NMDA receptors interactions in the striatum of Fischer rats. Brain Res Bull 80:377-381. CrossRef Medline

Surmeier DJ, Eberwine J, Wilson CJ, Cao Y, Stefani A, Kitai ST (1992) Dopamine receptor subtypes colocalize in rat striatonigral neurons. Proc Natl Acad Sci U S A 89:10178-10182. CrossRef Medline

Suto N, Ecke LE, You ZB, Wise RA (2010) Extracellular fluctuations of dopamine and glutamate in the nucleus accumbens core and shell associated with lever-pressing during cocaine self-administration, extinction, and yoked cocaine administration. Psychopharmacology (Berl) 211:267-275. CrossRef Medline

Tanaka K, Watase K, Manabe T, Yamada K, Watanabe M, Takahashi K, Iwama H, Nishikawa T, Ichihara N, Kikuchi T, Okuyama S, Kawashima N, Hori S, Takimoto M, Wada K (1997) Epilepsy and exacerbation of brain injury in mice lacking the glutamate transporter GLT-1. Science 276:1699-1702. CrossRef Medline

Thanos PK, Bermeo C, Wang GJ, Volkow ND (2011) D-cycloserine facilitates extinction of cocaine self-administration in rats. Synapse 65:938944. CrossRef Medline

Thomas CG, Miller AJ, Westbrook GL (2006) Synaptic and extrasynaptic NMDA receptor NR2 subunits in cultured hippocampal neurons. J Neurophysiol 95:1727-1734. CrossRef Medline

Tong H, Gibb AJ (2008) Dopamine D1 receptor inhibition of NMDA receptor currents mediated by tyrosine kinase-dependent receptor trafficking in neonatal rat striatum. J Physiology 586:4693-4707. CrossRef Medline

Tovar KR, Westbrook GL (1999) The incorporation of NMDA receptors with a distinct subunit composition at nascent hippocampal synapses in vitro. J Neurosci 19:4180-4188. Medline

Tzingounis AV, Wadiche JI (2007) Glutamate transporters: confining runaway excitation by shaping synaptic transmission. Nat Rev Neurosci 8:935-947. Medline 
Vicini S, Wang JF, Li JH, Zhu WJ, Wang YH, Luo JH, Wolfe BB, Grayson DR (1998) Functional and pharmacological differences between recombinant N-methyl-D-aspartate receptors. J Neurophysiol 79:555-566. Medline

Wang M, Wong AH, Liu F (2012) Interactions between NMDA and dopamine receptors: a potential therapeutic target. Brain Res 1476:154-163. CrossRef Medline

Wenthold RJ, Prybylowski K, Standley S, Sans N, Petralia RS (2003) Trafficking of NMDA receptors. Annu Rev Pharmacol Toxicol 43:335-358. Medline

Wittmann M, Queisser G, Eder A, Wiegert JS, Bengtson CP, Hellwig A, Wit- tum G, Bading H (2009) Synaptic activity induces dramatic changes in the geometry of the cell nucleus: interplay between nuclear structure, histone $\mathrm{H} 3$ phosphorylation, and nuclear calcium signaling. J Neurosci 29:14687-14700. CrossRef Medline

Yamamoto DJ, Zahniser NR (2012) Differences in rat dorsal striatal NMDA and AMPA receptors following acute and repeated cocaine-induced locomotor activation. PLoS One 7:e37673. CrossRef Medline

Zheng K, Scimemi A, Rusakov DA (2008) Receptor actions of synaptically released glutamate: the role of transporters on the scale from nanometers to microns. Biophys J 95:4584-4596. Medline 